\title{
Changes in the Phenolic Composition and Antioxidant Activity of Pinotage, Cabernet Sauvignon, Chardonnay and Chenin blanc Wines During Bottle Ageing
}

\author{
D. de Beer ${ }^{1}$, E. Joubert ${ }^{2 *}$, W.C.A. Gelderblom ${ }^{3}$ and M. Manley ${ }^{1}$ \\ (1) Department of Food Science, Stellenbosch University, Private Bag X1, 7602 Matieland (Stellenbosch), South Africa \\ (2) ARC Infruitec-Nietvoorbij, Private Bag X5026, 7599 Stellenbosch, South Africa \\ (3) Programme for Mycotoxins and Experimental Carcinogenesis (PROMEC), Medical Research Council, P.O. Box 19070, 7505 \\ Tygerberg, South Africa
}

Submitted for publication: March 2004

Accepted for publication: January 2005

Key words: Antioxidants, free radical scavenging, phenolic compounds, wine ageing

\begin{abstract}
The effect of bottle ageing on the antioxidant activity of Pinotage, Cabernet Sauvignon, Chardonnay and Chenin blanc wines, using the 2,2'-azino-di-(3-ethylbenzothialozine-sulphonic acid) radical cation (ABTS ${ }^{\circ+}$ ) and 2,2-diphenyl-1-picrylhydrazyl radical (DPPH') scavenging assays, was determined. Storage at $0^{\circ} \mathrm{C}, 15^{\circ} \mathrm{C}$ or $30^{\circ} \mathrm{C}$ for a period of 12 months resulted in a significant $(p \leq 0.05)$ decrease in both the total antioxidant activity (TAA ABTS $_{\text {and }}$ TAA $_{\mathrm{DPPH}}$ ) and the total phenol content of the wines. The antioxidant potency of the total phenols of most of the wines, which is a ratio of antioxidant activity to the total phenol content, also decreased. The total anthocyanins in the red wines decreased significantly $(p \leq 0.05)$ over 12 months except for storage at $0^{\circ} \mathrm{C}$, while the flavanol content of the Pinotage, Cabernet Sauvignon and Chardonnay wines increased up to nine months storage with a subsequent decrease to 12 months. The flavonol content of all the wines decreased, while only minor changes in their hydroxycinnamate content were observed during the storage period. Understanding the complexity of these reactions may provide clues for stabilising especially red wines to preserve the antioxidant activity without losing the beneficial effects of colouring and flavour development during bottle ageing.
\end{abstract}

The ability of wines and other foods to prevent free radical-mediated diseases has been investigated recently (Halliwell \& Gutteridge, 1990; Davies, 1995; Leake, 1998). The possible health-promoting properties of wine are related in part to phenolic compounds and their ability to act as antioxidants (Kinsella et al., 1993). In view of the greater health awareness among the public in terms of their diet, the antioxidant content or antioxidant potential may become a factor in determining the acceptability and marketability of wine and other foodstuffs. More information is, however, needed on the effect of technological factors and storage conditions on the antioxidant parameters of wine prior to consumption. Various technological factors relating to vineyard and vinification practices (Hurtado et al., 1997; Pellegrini et al., 2000), as well as the effect of cultivar (De Beer et al., 2003), were shown to alter the phenolic content and antioxidant activity of red and white wines.

Bottle ageing is important for the improvement of red wine quality (Somers \& Pocock, 1990). For white wine it can contribute to quality defects such as non-enzymatic browning and over-maturation, although some white wines may derive shortterm benefit from the development of a characteristic bottle bouquet (Marais \& Pool, 1980). Conflicting reports regarding the effect of ageing on the antioxidant activity of red wines have been published. Manzocco et al. (1998) and Okuda et al. (2002) reported a decrease in 2,2-diphenyl-1-picrylhydrazyl radical (DPPH*) scavenging activity for older wines based on the scavenging rate and total radical scavenging activity, respectively. Larrauri et al. (1999), however, showed an increase in antiradical efficiency (a parameter combining the amount of total phenols needed and the time required to scavenge $50 \%$ of the initial free radicals) of red wines with increased ageing status when using the $\mathrm{DPPH}^{\bullet}$ scavenging assay. In these studies, however, changes in antioxidant activity were not measured over time. Wines of different vintages were analysed in a single experiment. The differences in the original composition and antioxidant activity of the wines, as well as storage conditions, were also not taken into account. Manzocco et al. (1998) analysed two wines only, while Larrauri et al. (1999) used wines matured in wood for different periods. These factors, as well as differences in methodology, i.e. use of different end-points and DPPH ${ }^{\bullet}$ concentrations used, could have contributed to the conflicting outcomes of these studies. Zafrilla et al. (2003) report no change in 2,2'-azino-di-(3-ethylbenzothialozine-sulphonic acid) (ABTS) radical cation scavenging during seven months storage at $20^{\circ} \mathrm{C}$.

Changes in phenolic composition of red wine occur during bottle ageing, depending on the concentration of the individual phe-

\footnotetext{
*Corresponding author: E-mail address:joubertl@arc.agric.za

Acknowledgements: We are grateful to the South African wine industry (Winetech), the National Research Foundation (NRF) and the Technology and Human Resources for Industry Programme (THRIP) for financial support. We also thank Morné Lamont for statistical analysis of data.
} 
nolic compounds present, the storage temperature, the presence of oxygen and the sulphur dioxide content (Ribereau-Gayon \& Glories, 1986). Bottle ageing of red wine is the result of mostly anaerobic processes involving the copigmentation and polymerisation of anthocyanins, although some oxygen is present initially (Somers \& Pocock, 1990; Dallas \& Laureano, 1994). Copigmentation involves the hydrophobic stacking of anthocyanins with flavanols such as (+)-catechin and (-)-epicatechin, and a variety of phenolic acids. It is hypothesized to be the first step in the formation of covalent bonds during condensation reactions (Brouillard \& Dangles, 1994; Boulton, 2001). Formation of these complexes is favoured by low temperatures (Mazza, 1995). Hydroxyl groups, which confer antioxidant activity to phenolic compounds (Rice-Evans et al., 1996), are generally not involved during condensation reactions (Singleton, 1987). After condensation, hydroxyl moieties may be less available for reaction with free radical species due to steric hindrance (Yoshida et al., 1989). A large number of compounds, formed as products of condensation reactions, have been elucidated (Jurd, 1967; Fulcrand et al., 1997; Fulcrand et al., 1998; Remy et al., 2000). Other reactions in red wines during ageing include self-dissociation of procyanidin dimers yielding monomers and trimers (Haslam, 1980).

Reactions in white wines after fermentation mostly involve non-enzymatic, oxidative browning (Ribéreau-Gayon et al., 2000). Oxidation of ortho-dihydroxyphenolic compounds such as $(+)$-catechin, (-)-epicatechin, caffeic acid and other hydroxycinnamic acids leads to the formation of yellow or brown products due to the polymerisation of ortho-quinones (Singleton, 1987; Guyot et al., 1996). Other constituents of wine such as metal ions and sulphur dioxide can play a role in these oxidation reactions (Singleton, 1987; Cilliers \& Singleton, 1990). Sulphur dioxide and ascorbic acid added to wine are able to reduce the ortho-quinones, while metal ions can catalyse oxidation reactions (Singleton, 1987). Only limited information is available about the effect of changes in phenolic composition during bottle ageing of white wines on their antioxidant activity.

The aim of the study was to determine the effect of bottle ageing on the antioxidant activity of South African red (Pinotage and Cabernet Sauvignon) and white (Chardonnay and Chenin blanc) cultivar wines in relation to changes in their phenolic composition at different storage temperatures $\left(0^{\circ} \mathrm{C}, 15^{\circ} \mathrm{C}\right.$ and $\left.30^{\circ} \mathrm{C}\right)$ over a 12 month period.

\section{MATERIALS AND METHODS}

\section{Wines}

Grapes were harvested in February 2000 from the Nietvoorbij vineyards at $23.0^{\circ} \mathrm{B}, 23.5^{\circ} \mathrm{B}, 21.9^{\circ} \mathrm{B}$ and $20.1^{\circ} \mathrm{B}$ for Pinotage, Cabernet Sauvignon, Chardonnay and Chenin blanc, respectively. Three batches (replicates) of grapes from each grape cultivar were processed. Wines were prepared according to the standard Nietvoorbij procedure for small-scale winemaking at the ARC Infruitec-Nietvoorbij research institute. The vinification procedure for red wines was as follows: grapes were crushed, inoculated with VIN $13(30 \mathrm{~g} / \mathrm{HL})$ and fermented to $0^{\circ} \mathrm{B}$ at $24^{\circ} \mathrm{C}$ after addition of $50 \mathrm{~g} / \mathrm{HL}$ di-ammoniumphosphate. During this period the cap was punched down three times a day. Before pressing, the free $\mathrm{SO}_{2}$ content was adjusted to $50 \mathrm{mg} / \mathrm{L}$. The skins were separated from the juice using a pneumatic press and pressed juice added to the free-run juice. After fermentation was completed, the free $\mathrm{SO}_{2}$ content was adjusted to $35 \mathrm{mg} / \mathrm{L}$ and $50 \mathrm{~g} / \mathrm{HL}$ bentonite added. Wines were then cold-stabilised for 2 weeks at $0^{\circ} \mathrm{C}$, filtered and bottled in $\mathrm{N}_{2}$-filled bottles at room temperature with adjustment of the free $\mathrm{SO}_{2}$ content to $40 \mathrm{mg} / \mathrm{L}$. The vinification procedure for the white wines was similar to that of red wines, except that pressing occurred directly after crushing. Overnight clarification was done after pressing using pectolytic enzymes and fermentation of white musts occurred at $15^{\circ} \mathrm{C}$. No ascorbic acid was added during vinification of white wines.

The wines were stored at $0^{\circ} \mathrm{C}, 15^{\circ} \mathrm{C}$ and $30^{\circ} \mathrm{C}$ for 12 months in dark, temperature-controlled rooms directly after bottling in June 2000. One bottle of each batch and cultivar/temperature combination was sampled at the start of the experiment followed by sampling at 3-month intervals up to 12 months. Aliquots were frozen at $-18^{\circ} \mathrm{C}$ in plastic screw-top sample holders $(40 \mathrm{~mL})$ until analysed. Samples were defrosted and sonicated to dissolve precipitates before analysis, which occurred within one month of sampling.

\section{Chemicals}

Folin-Ciocalteau's phenol reagent, 4-dimethylamino-cinnamaldehyde (DAC), 6-hydroxy-2,5,7,8-tetra-methylchroman-2-carboxylic acid (Trolox), potassium persulphate $\left(\mathrm{K}_{2} \mathrm{~S}_{2} \mathrm{O}_{8}\right),(+)$-catechin, gallic acid, caffeic acid and quercetin were obtained from commercial sources (Fluka, Buchs, Switzerland; Riedel-de-Haen, Seelze, Germany; Sigma, St Louis, USA; Aldrich, Steinheim, Germany; Merck, Darmstadt, Germany). The 2,2'-azino-di(3-ethylbenzo-thialozine-sulphonate) diammonium salt (ABTS) was obtained from Boehringer Mannheim GmbH (Mannheim, Germany). The water was purified and de-ionised with a Modulab water purification system prior to use (Separations, Cape Town, South Africa).

\section{Measurement of the ABTS ${ }^{\bullet+}$ and DPPH` scavenging activity}

The total antioxidant activity (TAA) of wines was determined using the ABTS ${ }^{\bullet+}$ scavenging assay of Re et al. (1999) and the DPPH' scavenging assay of Brand-Williams et al. (1995), with minor modifications as described in De Beer et al. (2003).

The concentration of ABTS ${ }^{*+}$ in the control and samples was calculated using the absorbance readings and the extinction coefficient of $\mathrm{ABTS}^{\circ+}$, i.e. $\mathrm{e}=16000$ ( $\operatorname{Re}$ et al., 1999), while the concentration of DPPH ${ }^{*}$ was calculated using a standard curve of known concentrations of $\mathrm{DPPH}^{\bullet}$ against the absorbance at $515 \mathrm{~nm}$ :

$$
\left[\mathrm{DPPH}^{\bullet}\right]=\frac{\text { Absorbance }(515 \mathrm{~nm})-0.0065}{0.1127}
$$

A plot of remaining $\mathrm{ABTS}^{*+}$ and $\mathrm{DPPH}^{*}$ concentration against the concentration of Trolox in the standard samples was used to calculate the TAA $A_{A B T S}$ and TAA $A_{D P P H}$ of the wines. The antioxidant potency (AP) of the total phenols for each wine was calculated as the ratio of TAA to total phenols:

$$
\mathrm{AP}=\frac{\mathrm{TAA}}{\text { Total phenols }} \times 1000
$$

\section{Determination of the phenolic composition}

Spectrophotometric methods were used to determine the total phenol (Singleton \& Rossi, 1965), anthocyanin (Burns et al., 2000), flavanol (McMurrough \& McDowell, 1978), flavonol and 
hydroxycinnamate (Mazza et al., 1999) contents of the wines. The total phenol and flavanol analyses are based on the reaction of polyphenols and flavanols with the Folin-Ciocalteau and DAC reagents, respectively. The anthocyanin determination is based on the difference in absorbance at $\mathrm{pH}<1$ and $\mathrm{pH} 3.5$ for monomeric and polymeric anthocyanins. The flavonol and hydroxycinnamate determination is based on their absorbance at 320 and 360 $\mathrm{nm}$, respectively. Results were expressed as mg gallic acid equivalents/L (mg GAE/L), mg malvidin-3-glucoside (Mv-3-glc) equivalents/L, mg catechin equivalents/L (mg CE/L), mg quercetin equivalents/L (mg QE/L) and $\mathrm{mg}$ caffeic acid equivalents/L (mg CAE/L), respectively. Structures of phenolic compounds from these phenolic groups are shown in Figure 1 as examples. Spectrophotometric measurements were performed on a Beckman DU-65 UV/VIS spectrophotometer (Beckman, Cape Town, South Africa) using a $1 \mathrm{~cm}$ path length quartz cuvette.

\section{Statistical analysis}

Each replicate was analysed in triplicate directly after sampling. Treatment combinations (cultivar and temperature) within the same storage period were analysed in random order. One-way ANOVA was used to determine whether the means for different treatment combinations differed significantly. Statistical comparison between different treatment combinations was made using the Student's t-LSD test $(p \leq 0.05)$. Correlations between antioxidant parameters and phenolic content were done using Pearson's product moment correlation coefficient. Correlations were deemed to be significant when $p<0.001$. The SAS version 6.12 software package was used for statistical analysis.

\section{RESULTS AND DISCUSSION}

\section{Phenolic composition}

\section{Total phenol content}

The total phenol content of the red wines decreased (Fig. 2A) between $10.2 \%$ and $16.5 \%$ as a function of time at the different storage temperatures. The final total phenol content of Pinotage wines was significantly lower than the initial content, except for Pinotage stored at $15^{\circ} \mathrm{C}$ (Table 1). The decrease of total phenol content occurred faster at higher temperatures, as significant differences (not shown) from the initial values were observed after a shorter time. No further decrease in total phenols occurred from nine to 12 months storage. However, after 12 months storage there were no significant differences in total phenol content of wines stored at different temperatures (Table 1).

White wines exhibited a decrease in total phenol content (Fig. 2B) of between $5.7 \%$ and $17.2 \%$ during storage at the different temperatures. As for red wines, storage at higher temperatures caused a faster decrease in total phenol content. The final total phenol content of Chardonnay and Chenin blanc wines stored at $30^{\circ} \mathrm{C}$ was significantly lower than with storage at $0^{\circ} \mathrm{C}$ (Table 2 ).

A decrease in the total phenol content of red and white wines indicates a loss of reactive hydroxyl groups (Singleton et al., 1999) due to the oxidation of phenolic compounds (Singleton, 1987). Furthermore, some condensation reactions involving the hydroxyl moieties of anthocyanins could have contributed to this phenomenon (Remy-Tanneau et al., 2003). The incorporation of monomeric phenolic compounds into polymeric structures might reduce their reactivity with the Folin-Ciocalteau reagent due to steric hindrance.<smiles></smiles><smiles>Oc1cc(O)c2c(c1)O[C@H](c1ccc(O)c(O)c1)[C@H](O)C2</smiles><smiles>[2H]c1cc(-c2oc3cc(O)cc(O)c3c(=O)c2O)cc(Br)c1O</smiles>

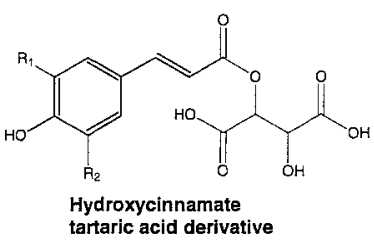

FIGURE 1

Representative structures for the major phenolic groups present in wine.

A.

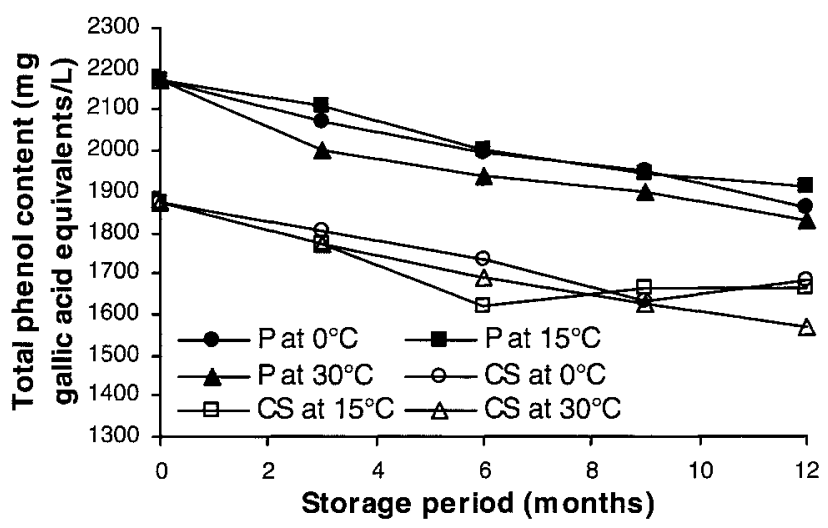

B.

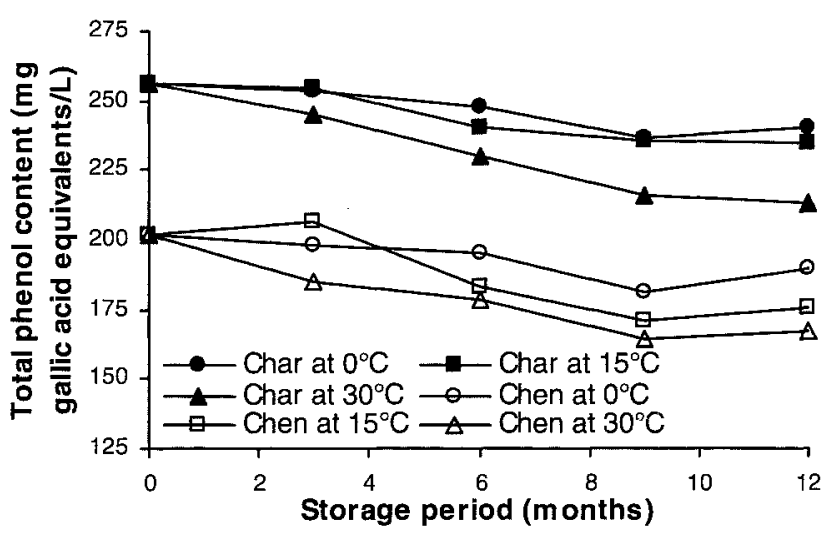

FIGURE 2

Change in the total phenol content of bottled red (A) and white (B) wines during storage at $0^{\circ} \mathrm{C}, 15^{\circ} \mathrm{C}$ and $30^{\circ} \mathrm{C}(\mathrm{P}=$ Pinotage; $\mathrm{CS}=$ Cabernet Sauvignon; Char = Chardonnay; Chen $=$ Chenin blanc) 
TABLE 1

Initial and final phenolic composition of bottled red wines stored at different temperatures.

\begin{tabular}{|c|c|c|c|c|}
\hline \multirow{2}{*}{ Phenolic group/Cultivar } & \multirow{2}{*}{ Initial $^{a}$} & \multicolumn{3}{|c|}{ Final $^{\mathrm{b}}$} \\
\hline & & $0^{\circ} \mathrm{C}$ & $15^{\circ} \mathrm{C}$ & $30^{\circ} \mathrm{C}$ \\
\hline \multicolumn{5}{|l|}{ Pinotage } \\
\hline Total phenols ${ }^{\mathfrak{c}}$ & $\begin{array}{c}2171.99 a^{d} \\
( \pm 172.80)^{e}\end{array}$ & $\begin{array}{r}1861.45 b \\
( \pm 174.81)\end{array}$ & $\begin{array}{l}1913.46 \mathrm{ab} \\
( \pm 132.48)\end{array}$ & $\begin{array}{l}1830.86 b \\
( \pm 148.26)\end{array}$ \\
\hline Total anthocyanins ${ }^{\mathrm{f}}$ & $\begin{array}{l}474.25 \mathrm{a} \\
( \pm 68.64)\end{array}$ & $\begin{array}{l}426.84 \mathrm{a} \\
( \pm 59.97)\end{array}$ & $\begin{array}{l}335.90 \mathrm{~b} \\
( \pm 48.09)\end{array}$ & $\begin{array}{l}110.38 \mathrm{c} \\
( \pm 21.94)\end{array}$ \\
\hline Monomeric anthocyanins ${ }^{f}$ & $\begin{array}{c}411.58 \mathrm{a} \\
( \pm 59.86)\end{array}$ & $\begin{array}{l}363.06 \mathrm{~b} \\
( \pm 51.79)\end{array}$ & $\begin{array}{c}273.45 \mathrm{c} \\
( \pm 38.73)\end{array}$ & $\begin{array}{r}\quad 62.12 d \\
( \pm 16.22)\end{array}$ \\
\hline Polymeric anthocyanins ${ }^{f}$ & $\begin{array}{l}62.67 a b \\
( \pm 8.78)\end{array}$ & $\begin{array}{l}63.78 \mathrm{a} \\
( \pm 8.22)\end{array}$ & $\begin{array}{l}62.45 \mathrm{ab} \\
( \pm 9.37)\end{array}$ & $\begin{array}{r}48.26 \mathrm{~b} \\
( \pm 6.08)\end{array}$ \\
\hline Flavanolsg & $\begin{array}{l}176.35 \mathrm{ab} \\
( \pm 15.38)\end{array}$ & $\begin{array}{l}148.36 b \\
( \pm 19.72)\end{array}$ & $\begin{array}{l}171.49 \mathrm{ab} \\
( \pm 19.30)\end{array}$ & $\begin{array}{c}195.32 \mathrm{a} \\
( \pm 25.12)\end{array}$ \\
\hline Flavonols $^{h}$ & $\begin{array}{c}144.70 \mathrm{a} \\
( \pm 14.48)\end{array}$ & $\begin{array}{l}113.96 \text { bc } \\
( \pm 20.50)\end{array}$ & $\begin{array}{l}121.37 \mathrm{abc} \\
( \pm 14.50)\end{array}$ & $\begin{array}{r}107.30 \mathrm{c} \\
( \pm 23.40)\end{array}$ \\
\hline Hydroxycinnamates ${ }^{\mathrm{i}}$ & $\begin{array}{c}300.82 \mathrm{a} \\
( \pm 21.12)\end{array}$ & $\begin{array}{l}300.82 \mathrm{a} \\
( \pm 23.88)\end{array}$ & $\begin{array}{l}311.21 \mathrm{a} \\
( \pm 21.13)\end{array}$ & $\begin{array}{r}305.89 \mathrm{a} \\
( \pm 27.14)\end{array}$ \\
\hline \multicolumn{5}{|l|}{ Cabernet Sauvignon } \\
\hline Total phenols ${ }^{c}$ & $\begin{array}{l}1874.31 \mathrm{a} \\
( \pm 80.95)\end{array}$ & $\begin{array}{l}1682.96 \mathrm{~b} \\
( \pm 38.63)\end{array}$ & $\begin{array}{l}1665.47 \mathrm{~b} \\
( \pm 71.63)\end{array}$ & $\begin{array}{l}1565.47 \mathrm{~b} \\
( \pm 58.67)\end{array}$ \\
\hline Total anthocyanins ${ }^{f}$ & $\begin{array}{c}452.67 a \\
( \pm 26.23)\end{array}$ & $\begin{array}{l}407.44 \mathrm{a} \\
( \pm 25.43)\end{array}$ & $\begin{array}{l}315.57 \mathrm{~b} \\
( \pm 22.09)\end{array}$ & $\begin{array}{l}113.52 \mathrm{c} \\
( \pm 7.11)\end{array}$ \\
\hline Monomeric anthocyanins ${ }^{f}$ & $\begin{array}{c}380.39 a \\
( \pm 22.73)\end{array}$ & $\begin{array}{l}335.61 \mathrm{~b} \\
( \pm 20.49)\end{array}$ & $\begin{array}{l}247.44 \mathrm{c} \\
( \pm 19.13)\end{array}$ & $\begin{array}{l}58.61 \mathrm{~d} \\
( \pm 7.17)\end{array}$ \\
\hline Polymeric anthocyanins ${ }^{\mathrm{f}}$ & $\begin{array}{c}72.28 \mathrm{a} \\
( \pm 4.61)\end{array}$ & $\begin{array}{c}71.84 \mathrm{a} \\
( \pm 5.24)\end{array}$ & $\begin{array}{c}68.14 \mathrm{a} \\
( \pm 4.91)\end{array}$ & $\begin{array}{r}54.91 b \\
( \pm 2.81)\end{array}$ \\
\hline Flavanols $\mathrm{g}$ & $\begin{array}{l}153.41 \mathrm{ab} \\
( \pm 5.90)\end{array}$ & $\begin{array}{l}141.13 \mathrm{c} \\
( \pm 3.88)\end{array}$ & $\begin{array}{l}146.69 \text { bc } \\
( \pm 6.37)\end{array}$ & $\begin{array}{l}157.59 \mathrm{a} \\
( \pm 3.37)\end{array}$ \\
\hline Flavonols $^{\mathrm{h}}$ & $\begin{array}{l}123.59 \mathrm{a} \\
( \pm 6.11)\end{array}$ & $\begin{array}{l}103.22 \mathrm{ab} \\
( \pm 9.62)\end{array}$ & $\begin{array}{l}95.44 \mathrm{~b} \\
( \pm 8.39)\end{array}$ & $\begin{array}{l}99.52 b \\
( \pm 8.91)\end{array}$ \\
\hline Hydroxycinnamates ${ }^{\mathrm{i}}$ & $\begin{array}{l}203.24 b \\
( \pm 6.53)\end{array}$ & $\begin{array}{l}204.93 b \\
( \pm 7.57)\end{array}$ & $\begin{array}{l}206.62 \mathrm{~b} \\
( \pm 7.95)\end{array}$ & $\begin{array}{l}220.14 \mathrm{a} \\
( \pm 5.02)\end{array}$ \\
\hline
\end{tabular}

${ }^{a}$ Values at zero months of storage; ${ }^{b}$ Values at 12 months of storage; ${ }^{c}$ Total phenol content expressed as mg gallic acid equivalents/L; ${ }^{\mathrm{d}}$ Averages in a row followed by different letters differ significantly ( $p \leq 0.05$ ); ${ }^{e} \mathrm{SD}$; ${ }^{\mathrm{f}}$ Anthocyanin content expressed as mg malvidin-3-glucoside equivalents/L; ${ }^{\mathrm{g}} \mathrm{Flavanol}$ content expressed as mg catechin equivalents/L; hilavonol content expressed as mg quercetin equivalents/L; ${ }^{i}$ Hydroxycinnamate content expressed as mg caffeic acid equivalents/L.

The temperature-dependent decrease in the total phenol content of Pinotage occurred sooner than for Cabernet Sauvignon, while the decrease for Chenin blanc was faster than for Chardonnay. It is not known whether specific combinations of phenolic compounds could have a more stabilising effect on the change in phenolic composition, such as in the case of Cabernet Sauvignon and Chardonnay wines.

\section{Anthocyanin content}

The most noticeable change in red wine phenolic composition during ageing was observed for the monomeric anthocyanin content (Fig. 3A). Temperature had a significant effect on the final monomeric anthocyanin content (Table 1). An increase in temperature accelerated the decrease in monomeric anthocyanin content, resulting in an average reduction of $11.8 \%, 33.6 \%$ and $84.8 \%$ for storage at $0^{\circ} \mathrm{C}, 15^{\circ} \mathrm{C}$ and $30^{\circ} \mathrm{C}$, respectively. The general trend observed for the total anthocyanin content was similar to that for the monomeric anthocyanin content.
The polymeric anthocyanin content (Fig. 3B) did not change significantly over the 12 -months storage period at $0^{\circ} \mathrm{C}$ and $15^{\circ} \mathrm{C}$ for both Pinotage and Cabernet Sauvignon, but at $30^{\circ} \mathrm{C}$ a significant decrease of approximately $21.3 \%$ was observed (Table 1 ).

Previously, it was shown that individual anthocyanins, and especially monomeric anthocyanins, decreased faster when stored at a higher temperature (Somers \& Pocock, 1990). Apart from temperature, the presence of oxygen would also increase anthocyanin degradation (Ribéreau-Gayon et al., 2000). However, Nagel \& Wulf (1979) demonstrated a marked decrease during a seven-month period in anthocyanin content of wines (flushed with nitrogen) stored between $20^{\circ} \mathrm{C}$ and $22^{\circ} \mathrm{C}$, indicating the role of other factors. Results similar to those of Nagel \& Wulf (1979) were obtained by Gómez-Plaza et al. (2000) for a bottled red wine (not flushed with nitrogen) stored at ambient temperature (daily min. between $8^{\circ} \mathrm{C}$ and $22^{\circ} \mathrm{C}$; daily max. between $16^{\circ} \mathrm{C}$ and $36^{\circ} \mathrm{C}$ ) and in a cellar (temperature between $15^{\circ} \mathrm{C}$ and $20^{\circ} \mathrm{C}$ ) 
TABLE 2

Initial and final phenolic composition of bottled white wines stored at different temperatures.

\begin{tabular}{|c|c|c|c|c|}
\hline \multirow{2}{*}{ Phenolic group/Cultivar } & \multirow{2}{*}{ Initial $^{\mathbf{a}}$} & \multicolumn{3}{|c|}{ Final $^{b}$} \\
\hline & & $0^{\circ} \mathrm{C}$ & $15^{\circ} \mathrm{C}$ & $30^{\circ} \mathrm{C}$ \\
\hline \multicolumn{5}{|l|}{ Chardonnay } \\
\hline Total phenols ${ }^{\mathrm{c}}$ & $\begin{array}{l}256.32 a^{d} \\
( \pm 14.66)^{e}\end{array}$ & $\begin{array}{l}239.92 \mathrm{~b} \\
( \pm 3.49)\end{array}$ & $\begin{array}{l}234.76 \mathrm{~b} \\
( \pm 8.06)\end{array}$ & $\begin{array}{l}212.87 \mathrm{c} \\
( \pm 2.60)\end{array}$ \\
\hline Flavanolsg & $\begin{aligned} & 8.31 \mathrm{a} \\
( \pm & 1.16)\end{aligned}$ & $\begin{aligned} & 8.44 \mathrm{a} \\
( \pm & 1.58)\end{aligned}$ & $\begin{aligned} & 9.49 \mathrm{a} \\
( \pm & 0.21)\end{aligned}$ & $\begin{aligned} & 8.32 \mathrm{a} \\
( \pm & 0.48)\end{aligned}$ \\
\hline Flavonols ${ }^{\mathrm{h}}$ & $\begin{array}{l}19.69 \mathrm{a} \\
( \pm 1.55)\end{array}$ & $\begin{array}{l}17.95 b \\
( \pm 0.23)\end{array}$ & $\begin{array}{l}18.51 \mathrm{ab} \\
( \pm 0.36)\end{array}$ & $\begin{aligned} & 17.69 \mathrm{~b} \\
&( \pm 0.23)\end{aligned}$ \\
\hline Hydroxycinnamates $^{\mathrm{i}}$ & $\begin{array}{l}52.52 \mathrm{a} \\
( \pm 4.27)\end{array}$ & $\begin{array}{l}55.23 \mathrm{a} \\
( \pm 1.20)\end{array}$ & $\begin{array}{c}55.78 \mathrm{a} \\
( \pm 1.05)\end{array}$ & $\begin{array}{l}55.83 \mathrm{a} \\
( \pm 1.13)\end{array}$ \\
\hline \multicolumn{5}{|l|}{ Chenin blanc } \\
\hline Total phenols $\mathrm{s}^{\mathrm{c}}$ & $\begin{array}{c}201.42 \mathrm{a} \\
( \pm 10.08)\end{array}$ & $\begin{array}{l}190.01 \mathrm{ab} \\
( \pm 11.24)\end{array}$ & $\begin{array}{l}175.39 b c \\
( \pm 14.03)\end{array}$ & $\begin{array}{l}166.80 \mathrm{c} \\
( \pm 10.50)\end{array}$ \\
\hline Flavanolsg & $\begin{aligned} & 2.48 \mathrm{a} \\
&( \pm 0.08)\end{aligned}$ & $\begin{aligned} & 2.75 a \\
( \pm & 0.12)\end{aligned}$ & $\begin{aligned} & 2.66 \mathrm{a} \\
( \pm & 0.24)\end{aligned}$ & $\begin{aligned} & 2.50 \mathrm{a} \\
&( \pm 0.20)\end{aligned}$ \\
\hline Flavonols $^{h}$ & $\begin{array}{c}13.77 \mathrm{a} \\
( \pm 0.54)\end{array}$ & $\begin{array}{l}11.43 b \\
( \pm 0.95)\end{array}$ & $\begin{array}{l}12.14 b \\
( \pm 0.51)\end{array}$ & $\begin{array}{r}12.25 b \\
( \pm 0.71)\end{array}$ \\
\hline Hydroxycinnamates $^{i}$ & $\begin{array}{l}39.65 \mathrm{~b} \\
( \pm 1.91)\end{array}$ & $\begin{array}{l}39.00 \mathrm{~b} \\
( \pm 2.77)\end{array}$ & $\begin{array}{l}40.44 a b \\
( \pm 1.78)\end{array}$ & $\begin{array}{l}43.20 \mathrm{a} \\
( \pm 1.85)\end{array}$ \\
\hline
\end{tabular}

aValues at zero months of storage; ${ }^{b}$ Values at 12 months of storage; ${ }^{\mathrm{c}}$ Total phenol content expressed as mg gallic acid equivalents/L; ${ }^{\mathrm{d}}$ Averages in a row followed by different letters differ significantly $(p \leq 0.05)$; ${ }^{\mathrm{e}} \mathrm{SD}$; ${ }^{\mathrm{f}}$ Anthocyanin content expressed as mg malvidin-3-glucoside equivalents/L; gFlavanol content expressed as mg catechin equivalents/L; hFlavonol content expressed as mg quercetin equivalents/L; ${ }^{i} \mathrm{Hydroxycinnamate}$ content expressed as mg caffeic acid equivalents/L.

for up to one year. In both cases a decrease in individual anthocyanin concentrations was demonstrated. The decrease in the total and monomeric anthocyanin contents of Pinotage and Cabernet Sauvignon wines in the present study could therefore be attributed to the combined effect of thermal degradation, oxidative degradation and condensation reactions with other phenolic compounds such as flavanols and hydroxycinnamates (Timberlake \& Bridle, 1979; Somers \& Pocock, 1990; Ribéreau-Gayon et al., 2000). These condensation reactions also lead to the stabilisation of red wine colour due to the formation of polymeric pigments (Somers \& Pocock, 1990). No increase in polymeric content was, however, observed using the $\mathrm{pH}$ shift method. This is presumably due to the insensitivity of the method or a too short storage time for this study. Pyranoanthocyanins such as vitisin $\mathrm{A}$ and pinotin $\mathrm{A}$ are less susceptible to colour loss with increased $\mathrm{pH}$ than monomeric anthocyanins and will be included in the polymeric anthocyanin estimation (Schwarz et al., 2004).

\section{Flavanol content}

Changes in the flavanol content of the red wines during storage are shown in Fig. 4A. The flavanol content of red wines increased significantly (not shown) up to nine months storage with a subsequent significant decrease (not shown) to 12 months for Pinotage $\left(15^{\circ} \mathrm{C}\right.$ and $\left.30^{\circ} \mathrm{C}\right)$ and Cabernet Sauvignon $\left(30^{\circ} \mathrm{C}\right)$. Subsequently, at 12 months storage, the final flavanol content of all cultivar/temperature combinations, except for Cabernet Sauvignon wines stored at $0^{\circ} \mathrm{C}$, did not differ significantly from the initial values (Table 1). The final flavanol contents of Pinotage and Cabernet Sauvignon wines stored at $30^{\circ} \mathrm{C}$ were significantly higher than the same wines stored at $0^{\circ} \mathrm{C}$ (Table 1). Cabernet Sauvignon also exhibited a significantly higher final flavanol content for storage at $30^{\circ} \mathrm{C}$ compared to $15^{\circ} \mathrm{C}$ (Table 1).

The changes in flavanol content for Chardonnay wines (Fig. $4 \mathrm{~B})$ follow a similar trend to that of red wines. The flavanol content of Chenin blanc remained stable during storage (Fig. 4B). At 12 months storage no significant differences between the initial and final flavanol content were observed (Table 2). The flavanol content of Chenin blanc wines was near the detection limit of the DAC assay, possibly the reason for no change being observed during storage. The large difference in flavanol content between Chenin blanc and Chardonnay wines is possibly due to differences in ripeness as well as cultivar-related differences.

A previous study has shown that bottled white wines subjected to an accelerated browning test $\left(50^{\circ} \mathrm{C}\right)$ exhibited an increase in flavanol content after 12 weeks, with a simultaneous decrease in proanthocyanidin content (Mayén et al., 1997). The flavanols, (+)-catechin and (-)-epicatechin, of bottled red wines decreased in concentration during storage (Nagel \& Wulf, 1979; Gómez-Plaza et al., 2000), while no significant change in the content of dimers, procyanidin B2, B4 and B5, was observed (Gómez-Plaza et al., 2000). Flavanols could participate in condensation reactions with anthocyanins in red wines (Jurd, 1967; Timberlake \& Bridle, 1976), which would contribute to the decrease in flavanol content of Pinotage and Cabernet Sauvignon wines after nine months (Fig. 4A). The higher final flavanol content observed for red wines stored at $30^{\circ} \mathrm{C}$ could be due to differences in the extent of the reaction of flavanols with anthocyanins at higher temperatures (Mazza, 1995), although this was not 
observed in Pinotage wines. The anthocyanin level decreased significantly at this temperature and less anthocyanins would be available for reaction.

Furthermore, the method of determining flavanol content used in the present study depends on the reaction of flavanols and proanthocyanidins with DAC. When reacting with DAC, (+)-catechin and (-)-epicatechin exhibit a much higher colour yield than dimeric or trimeric proanthocyanidins (McMurrough \& McDowell, 1978). It is well known that disproportionation of proanthocyanidins can occur, with the resultant formation of a flavanol monomer and other products, causing a reduction in the mean degree of polymerisation (Timberlake \& Bridle, 1976; Haslam, 1980; Ribéreau-Gayon et al., 2000). A reduction in mean degree of polymerisation was noted by Vidal et al. (2002) during storage of proanthocyanidins in the presence of monomeric flavanols in a wine-like solution. As the reactivity of monomers and oligomers in the DAC assay differs, changes in the degree of polymerisation could account for the apparent initial increase in flavanol content (Figs 4A and B).

A.

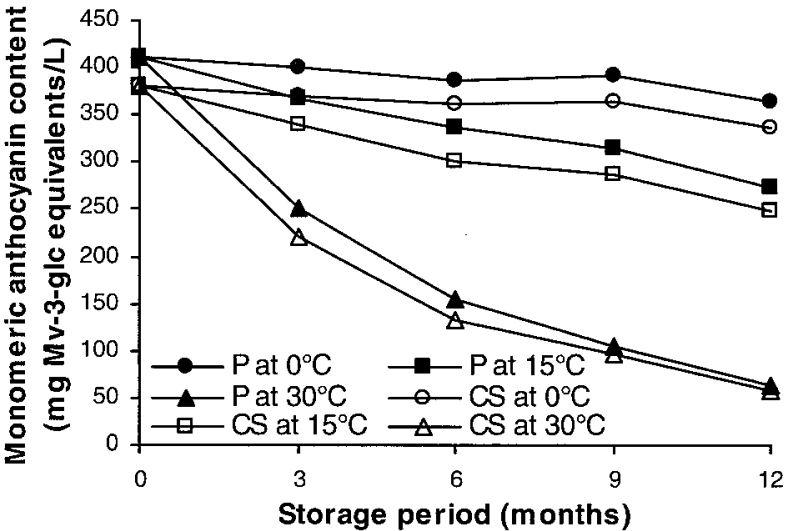

B.

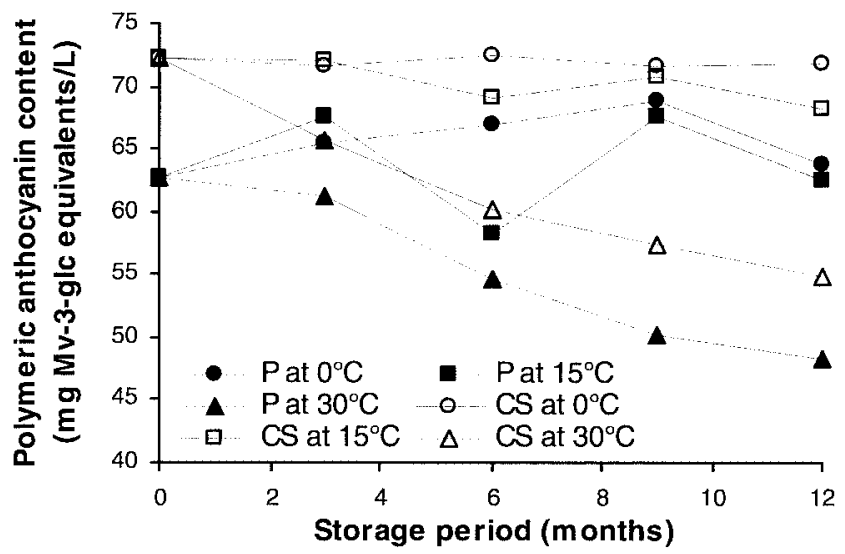

FIGURE 3

Change in the monomeric (A) and polymeric (B) anthocyanin content of bottled red wines during storage at $0^{\circ} \mathrm{C}, 15^{\circ} \mathrm{C}$ and $30^{\circ} \mathrm{C}(\mathrm{P}=$ Pinotage; $\mathrm{CS}=$ Cabernet Sauvignon).

\section{Flavonol content}

The flavonol content decreased significantly over the storage period for most of the red wine cultivar/temperature combinations, except for Pinotage at $15^{\circ} \mathrm{C}$ and Cabernet Sauvignon at $0^{\circ} \mathrm{C}$ (Table 1). The white wine flavonols were also significantly reduced (Table 2), but not to the same extent as those of the red wines. The different storage temperatures had no significant effect on the final flavonol content of the wines.

The decreased flavonol content in both red and white wines is presumably a result of oxidative degradation as this phenomenon was not temperature-dependent (Singleton, 1987). Previously, a decrease in flavonol content of white wines stored in contact with air for 30 days at $20^{\circ} \mathrm{C}$ was demonstrated using HPLC (Mayén et al., 1996). Zafrilla et al. (2003) reported a decrease in flavonol glycoside content coinciding with an increase in flavonol aglycon content, suggesting hydrolysis of flavonol glycosides during storage for seven months at $20^{\circ} \mathrm{C}$. If hydrolysis of flavonols occurs, the aglycons could also precipitate due to their poor solubility, thereby contributing to the decrease of this phenolic group.

A.

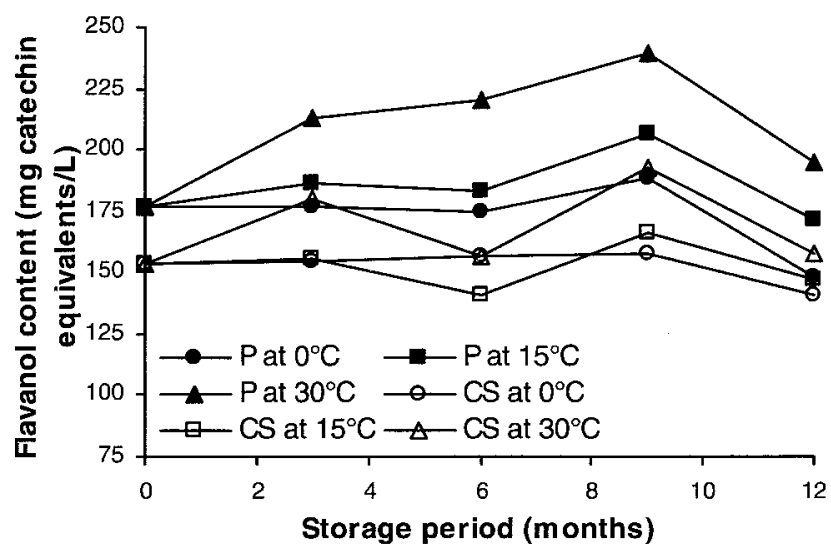

B.

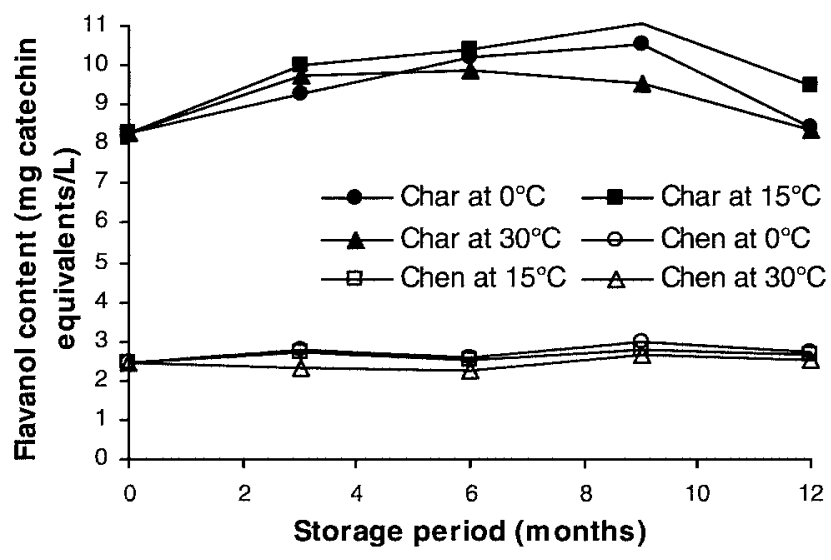

FIGURE 4

Change in the flavanol content of bottled red (A) and white (B) wines during storage at $0^{\circ} \mathrm{C}, 15^{\circ} \mathrm{C}$ and $30^{\circ} \mathrm{C}(\mathrm{P}=$ Pinotage; $\mathrm{CS}=$ Cabernet Sauvignon; Char $=$ Chardonnay; Chen $=$ Chenin blanc). 


\section{Hydroxycinnamate content}

The hydroxycinnamate content of Pinotage and Chardonnay did not alter during the storage period irrespective of the temperature (Tables $1 \&$ 2). For Cabernet Sauvignon and Chenin blanc, the hydroxycinnamate content was significantly increased (Table 1 \& 2) between $8 \%$ and $9 \%$, respectively, after 12 months storage at $30^{\circ} \mathrm{C}$.

The increase in hydroxycinnamate levels for Cabernet Sauvignon and Chenin blanc wines is contrary to results of previous studies. Mayén et al. (1997) showed that the hydroxycinnamate content decreased during an accelerated browning test of bottled white wines over a period of 12 weeks at $50^{\circ} \mathrm{C}$. Two other studies on red wines described a decrease in the levels of caffeoyl- and $p$-coumaroyltartaric acid (the two major hydroxycinnamates in wine) during storage for one year at ambient and cellar conditions (Gómez-Plaza et al., 2000) and for seven months between $20^{\circ} \mathrm{C}$ and $22^{\circ} \mathrm{C}$ (Nagel \& Wulf, 1979). The higher sensitivity of the HPLC methods used by Gómez-Plaza et al. (2000) and Nagel \& Wulf (1979) compared with the spectrophotometric estimations used in the present study possibly explains the different trends observed.

\section{Antioxidant activity}

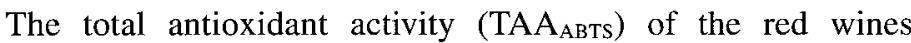
decreased at $0^{\circ} \mathrm{C}, 15^{\circ} \mathrm{C}$ and $30^{\circ} \mathrm{C}$ as a function of time (Fig. 5A), with Pinotage exhibiting higher TAA $\mathrm{ABTS}_{\text {and }}$ aAA $\mathrm{APPH}_{\mathrm{DPH}}$ values than Cabernet Sauvignon (Table 3). The TAA ${ }_{A B T S}$ and TAA ${ }_{D P P H}$ values for the red wines decreased significantly (Table 3 ) on average by $18.6^{\circ} \mathrm{C}$ and $34.5 \%$, respectively, over the 12 -month storage period. Only in the case of Cabernet Sauvignon did storage temperature have an effect on the final TAA values, with a significantly lower value being observed for storage at $30^{\circ} \mathrm{C}$ compared to $0^{\circ} \mathrm{C}$ at 12 months (Table 3 ).

Chardonnay exhibited higher TAA values than Chenin blanc. The TAA $\mathrm{ABTS}_{\mathrm{A}}$ and TAA $\mathrm{APPH}_{\mathrm{D}}$ values for the white wines decreased (Fig. 5B) on average by $18.9 \%$ and $50.2 \%$, respectively. Storage temperature had no significant effect on the final TAA $\mathrm{ABTS}_{\mathrm{B}}$ of Chenin blanc, while Chardonnay exhibited significantly lower final $\mathrm{TAA}_{\mathrm{ABTS}}$ values at $30^{\circ} \mathrm{C}$ (Table 4). The TAA $\mathrm{DPPH}_{\text {values were }}$ not significantly affected by temperature at 12 months storage.

In order to take into account the decrease in total phenol content, the AP of the wine total phenols was also calculated. A similar trend as for the TAA $\mathrm{ABTS}_{\mathrm{A} T \mathrm{~T}}$ and $\mathrm{TA} \mathrm{A}_{\mathrm{DPPH}}$ was noticed for the $\mathrm{AP}_{\mathrm{ABTS}}$ and $\mathrm{AP}_{\mathrm{DPPH}}$ values at the end of the storage period at the different temperatures for both the red and white wines (Tables 3 \& 4).

The present study shows that the efficiency of polyphenols in wines to scavenge free radicals decreased during storage as shown by the decrease in AP. Larrauri et al. (1999), however, reported an increase in antiradical efficiency (a parameter combining the concentration of sample required to obtain $50 \%$ scavenging and the time to reach a steady state) and a decrease in $\mathrm{EC}_{50}$ value with increasing ageing time of red wines. This change was attributed to an increase in tannic acid content, which could be ascribed to the fact that older wines were also subjected to longer wood treatments. The effects of wood maturation and bottle ageing were, therefore, not separated, which makes interpretation of their results difficult.
A.

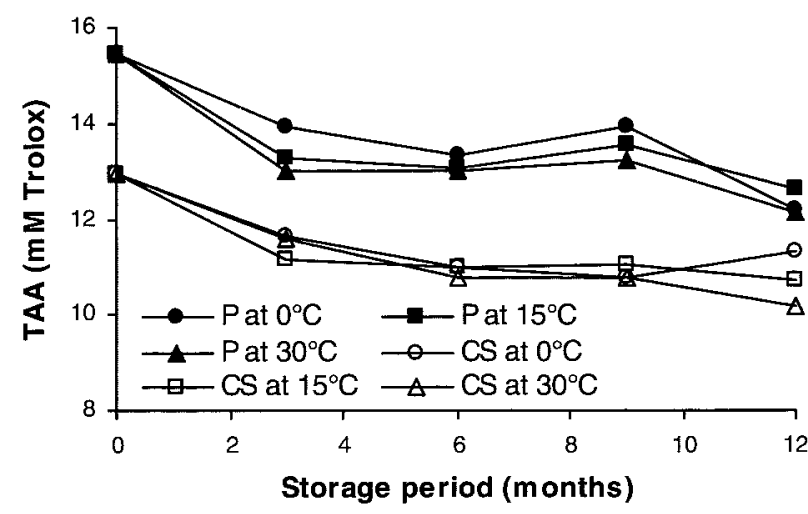

B.

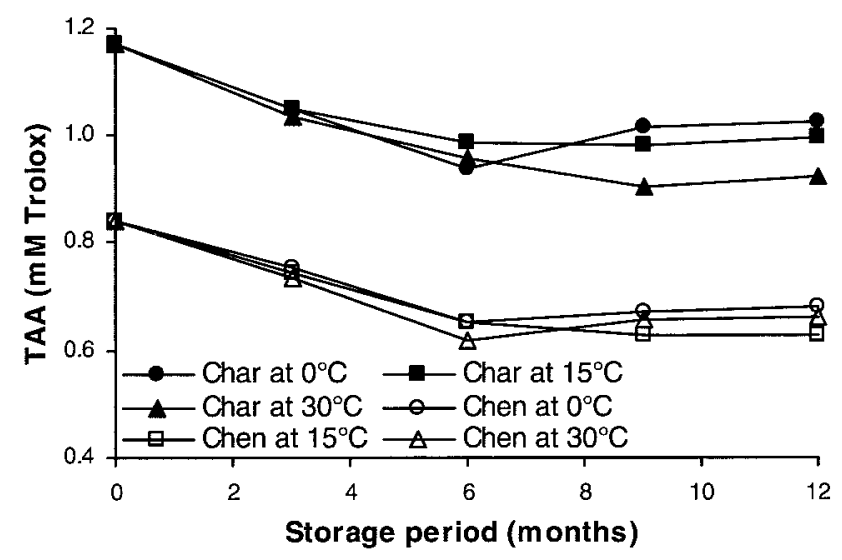

FIGURE 5

Change in total antioxidant activity (TAA) of bottled red (A) and white (B) wines during storage at $0^{\circ} \mathrm{C}, 15^{\circ} \mathrm{C}$ and $30^{\circ} \mathrm{C}(\mathrm{P}=$ Pinotage; $\mathrm{CS}=$ Cabernet Sauvignon; Char $=$ Chardonnay; Chen $=$ Chenin blanc $)$. The ABTS radical cation scavenging assay was used to measure total antioxidant activity.

The two free radical scavenging assays used in the present study exhibit similar results in monitoring the antioxidant activity of wines during bottle ageing, because both the TAA $\mathrm{ABTS}_{\mathrm{AB}}$ and $\mathrm{TAA}_{\mathrm{DPPH}}$ decreased during storage at all temperatures over a period of 12 months. Differentiation between the temperatures was possible using TAA $_{\mathrm{ABTS}}$ for Cabernet Sauvignon and Chardonnay wines, while TAA ${ }_{D P P H}$ failed to discriminate between different temperature treatments for any of the cultivars. The AP of wine total phenols calculated from $\mathrm{TAA}_{\mathrm{ABTS}}$ and $\mathrm{TA} \mathrm{A}_{\mathrm{DPPH}}$ did not exhibit the same trends. $\mathrm{AP}_{\mathrm{ABTS}}$ discriminated better between the initial and final values than $\mathrm{AP}_{\mathrm{DPPH}}$ in the case of Pinotage, while for Chenin blanc the opposite was true. Neither of these measurements differentiated between temperature treatments for the red or white wines, except for $\mathrm{AP}_{\mathrm{ABTS}}$ in the case of Cabernet Sauvignon. It would appear that the $\mathrm{ABTS}^{*+}$ scavenging assay is the more effective method to differentiate between wines subjected to different temperature treatments resulting in subtle differences in their phenolic composition. 
TABLE 3

Initial and final antioxidant activity of bottled red wines stored at different temperatures.

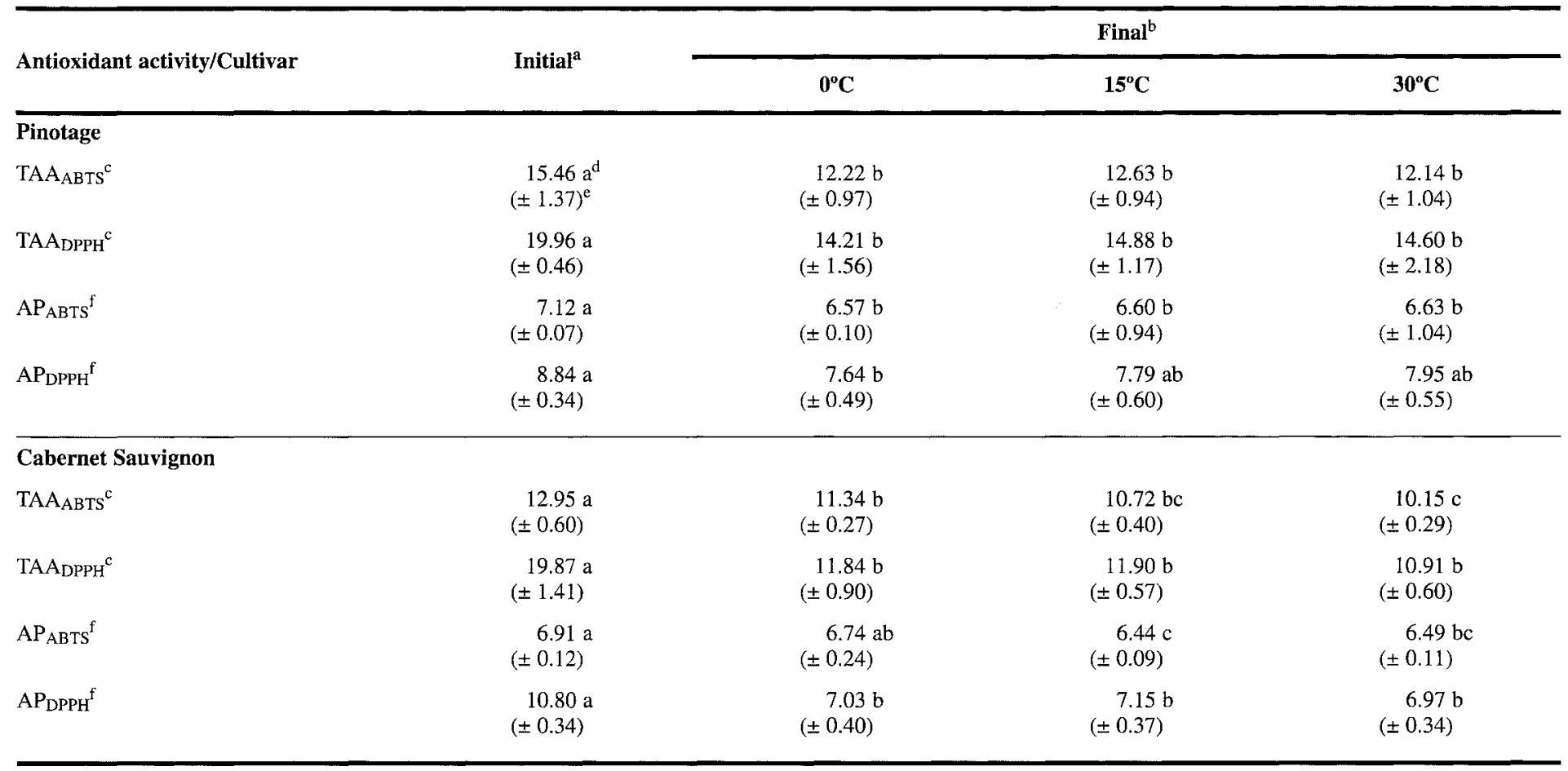

${ }^{a}$ Values at zero months of storage; ${ }^{\text {bValues at }} 12$ months of storage; ${ }^{\mathrm{c} T o t a l}$ antioxidant activity as mM Trolox equivalents measured using the ABTS radical cation or DPPH radical scavenging assay; ${ }^{\mathrm{d}}$ Averages in a row followed by different letters differ significantly $(\mathrm{p} \leq 0.05)$; ${ }^{\mathrm{e}} \mathrm{SD} ;{ }^{\mathrm{f}}$ Antioxidant potency $(\mathrm{AP})=\mathrm{TAA}(\mathrm{mM}$ Trolox $) \mathrm{X} 1000 /$ total phenols (mg gallic acid equivalents/L).

TABLE 4

Initial and final antioxidant activity of bottled white wines stored at different temperatures.

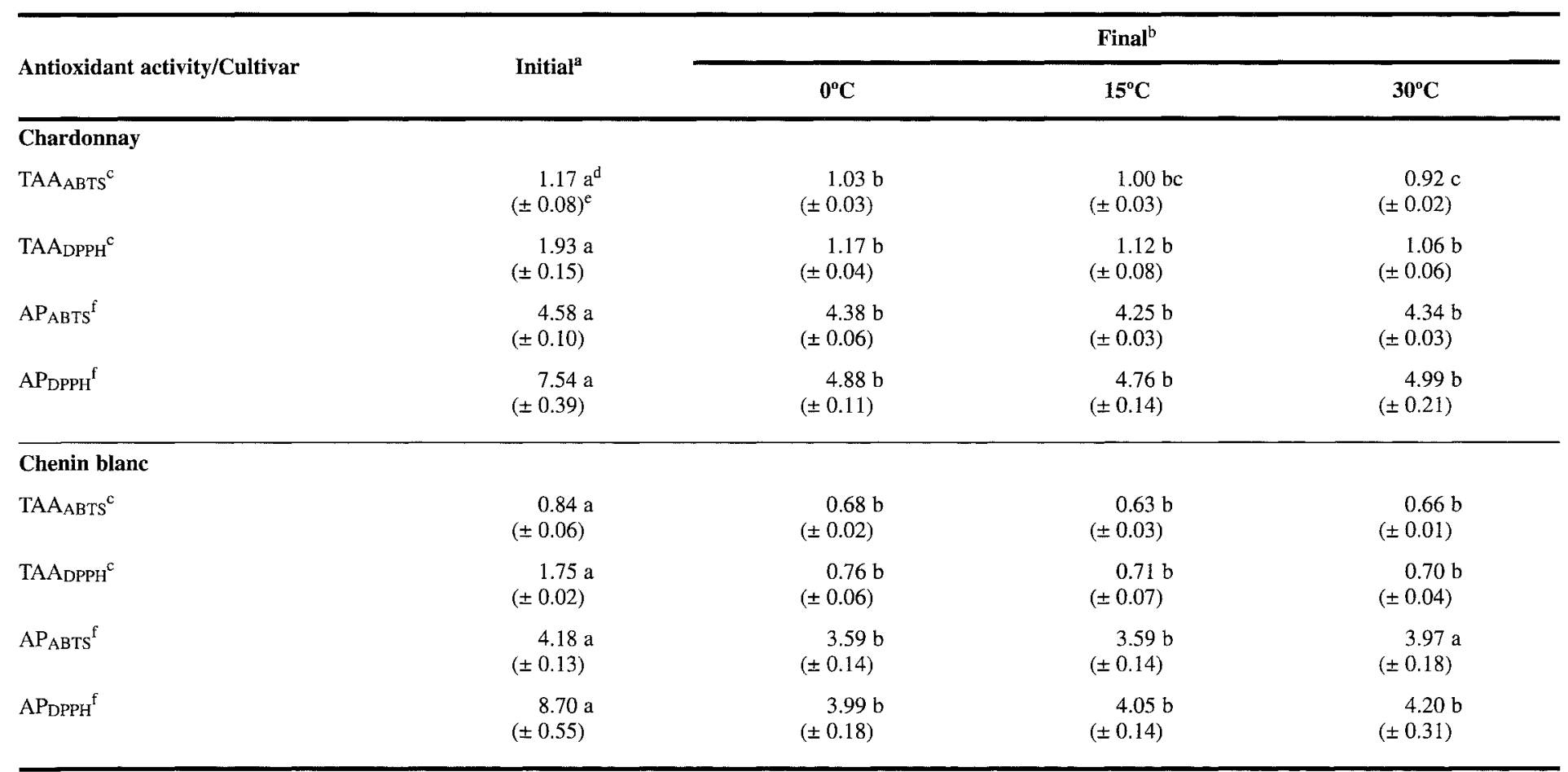

avalues at zero months of storage; ${ }^{b}$ Values at 12 months of storage; ${ }^{\mathrm{c}}$ Total antioxidant activity as mM Trolox equivalents measured using the ABTS radical cation or DPPH radical scavenging assay; ${ }^{\mathrm{d}}$ Averages in a row followed by different letters differ significantly $(\mathrm{p} \leq 0.05)$; ${ }^{\mathrm{S}} \mathrm{SD} ;{ }^{\mathrm{f}}$ Antioxidant potency $(\mathrm{AP})=\mathrm{TAA}(\mathrm{mM}$ Trolox $) \mathrm{X} 1000 /$ total phenols (mg gallic acid equivalents/L). 


\section{Correlation analysis}

The TAA $A_{A B T S}$ correlated with the total phenol content for red $(\mathrm{r}=0.93)$ and white $(\mathrm{r}=0.91)$ wines. Of the phenolic groups, flavonols $(\mathrm{r}=0.84)$ and hydroxycinnamates $(\mathrm{r}=0.71)$ in red wines, and flavanols $(r=0.81)$, flavonols $(r=0.87)$ and hydroxycinnamates $(r=0.78)$ in white wines, exhibited a good correlation with TAA $A_{\text {ABTs. }}$ The flavanol $(r=0.49)$ and monomeric anthocyanins $(r=0.50)$ content of red wine correlated weakly with $\mathrm{TAA}_{\mathrm{ABTS}}$. Correlations of the total phenol content and individual phenolic groups with $\mathrm{TAA}_{\mathrm{DPPH}}$ exhibited the same trends (data not shown).

The decrease in total antioxidant activity could be best explained by the decrease in total phenol content during bottle ageing of red and white wines as shown by the correlation analysis. The underlying changes in the individual phenolic groups are, however, also likely to play a contributory role in the decreased antioxidant activity of the wines. The initial rapid decrease in anthocyanin content of red wines at $15^{\circ} \mathrm{C}$ and $30^{\circ} \mathrm{C}$ may be the major determinants for the decrease in total antioxidant activity, although the initial increase in the flavanol content up to nine months storage could have an opposite effect. Possible hydrolysis of flavonol glycosides (Zafrilla et al., 2003) to the aglycons, which are more potent antioxidants (Rice-Evans et al., 1996), would also contribute to an increase in antioxidant activity. In addition, it is important to note that the antioxidant activity of the anthocyanins is generally less than that of the flavanols and flavonols (RiceEvans et al., 1996). These factors would explain the moderate decrease in total antioxidant activity. As the hydroxycinnamate content only changed during storage at $30^{\circ} \mathrm{C}$ and the flavanol content after 12 months storage was approximately the same as the initial content, the stabilisation of flavonols and anthocyanins seems to be an important target to protect wines against a loss in antioxidant activity. Changes in the phenolic groups determined in the present study gave only a broad picture and quantitative changes in individual phenolic compound levels need to be considered to provide a better understanding of the effect of the altered phenolic composition on the antioxidant activity of wines during ageing.

\section{CONCLUSIONS}

The present study shows that distinct changes, mostly decreases, in phenolic group concentrations affected not only the total antioxidant activity, but also the antioxidant potency of wine total phenols. The use of empirical methods estimating phenolic groups gave only a partial explanation of the changes in the antioxidant activity of wines during bottle ageing. Changes in individual phenolic compound levels during ageing should receive attention to fully explain their contribution to the total antioxidant activity of wines. The stabilisation of flavonols and anthocyanins in wines seems to be important in protection against loss of total antioxidant activity.

As wines are not normally consumed directly after production and a decrease of between $18 \%$ and $50 \%$ in total antioxidant activity could occur even under favourable storage conditions $\left(15^{\circ} \mathrm{C}\right)$ during one year, the use of total antioxidant activity values to market wines should be treated with caution.

\section{LITERATURE CITED}

Boulton, R., 2001. The copigmentation of anthocyanins and its role on the color of red wine: A critical review. Am. J. Enol. Vitic. 52, 67-87.

Brand-Williams, W., Cuvelier, M.E. \& Berset, C., 1995. Use of a free radical method to evaluate antioxidant activity. Food Sci. Technol. 28, 25-30.

Brouillard, R. \& Dangles, O., 1994. Anthocyanin molecular interactions: the first step in the formation of new pigments during wine aging? Food Chem. 51 , 365-371.

Burns, J., Gardner, P.T., O’Neil, J., Crawford, S., Morecroft, I., McPhail, D.B., Lister, C., Matthews, D., MacLean, M.R., Lean, M.E.J. \& Crozier, A., 2000. Relationship among antioxidant activity, vasodilation capacity, and phenolic content of red wines. J. Agric. Food Chem. 48, 220-230.

Cilliers, J.L. \& Singleton, V.L., 1990. Nonenzymatic autoxidative reactions of caffeic acid in wine. Am. J. Enol. Vitic. 41, 84-86.

Dallas, C. \& Laureano, O., 1994. Effect of pH, sulphur dioxide, alcohol content, temperature and storage time on colour composition of a young Portuguese red table wine. J. Sci. Food Agric. 65, 477-485.

Davies, K.J.A., 1995. Oxidative stress: the paradox of aerobic life. Biochem. Soc. Symp. 61, 1-31.

De Beer, D., Joubert, E., Gelderblom, W.C.A. \& Manley, M., 2003. Antioxidant activity of South African red and white cultivar wines: Free radical scavenging. $J$. Agric. Food Chem. 51, 902-909.

Fulcrand, H., Benabdeljalil, C., Rigaud, J., Cheynier, V. \& Moutounet, M., 1998. A new class of wine pigments generated by reaction between pyruvic acid and grape anthocyanins. Phytochem. 47, 1401-1407.

Fulcrand, H., Cheynier, V., Oszmianski, J. \& Moutounet, M., 1997. An oxidized tartaric acid residue as a new bridge potentially competing with acetaldehyde in flavan-3-ol condensation. Phytochem. 46, 223-227.

Gómez-Plaza, E., Gil-Muñoz, R., López-Roca, J.M. \& Martínez, A., 2000. Color and phenolic compounds of a young red wine. Influence of wine-making techniques, storage temperature, and length of storage time. J. Agric. Food Chem. 48 , 736-741.

Guyot, S., Vercauteren, J. \& Cheynier, V., 1996. Structural determination of colourless and yellow dimers resulting from $(+)$-catechin coupling catalysed by grape polyphenoloxidase. Phytochem. 42, 1279-1288.

Halliwell, B. \& Gutteridge, J.M.C., 1990. Role of free radicals and catalytic metal ions in human disease: An overview. Methods in Enzymol. 186, 1-85.

Haslam, E., 1980. In vino veritas: Oligomeric procyanidins and the aging of red wines. Phytochem. 19, 2577-2582.

Hurtado, I., Caldú, P., Gonzalo, A., Ramon, J.M., Mínguez, S. \& Fiol, C., 1997 Antioxidant capacity of wine on human low-density lipoprotein oxidation in vitro: Effect of skin contact in winemaking of white wine. J. Agric. Food Chem. 45, 1283-1289

Jurd, L., 1967. Anthocyanins and related compounds. Catechin-flavylium salt condensation reactions. Tetrahedron 23, 1057-1064.

Kinsella, J.E., Frankel, E., German, B. \& Kanner, J., 1993. Possible mechanisms for the protective role of antioxidants in wine and plant foods. Food Technol. 47, 85-89.

Larrauri, J.A., Sánchez-Moreno, C., Rupérez, P. \& Saura-Calixto, F., 1999. Free radical scavenging capacity in the aging of selected red Spanish wines. J. Agric. Food Chem. 47, 1603-1606.

Leake, D.S., 1998. Effects of flavonoids on the oxidation of low-density lipoproteins. In: Rice-Evans, C.A. \& Packer, L. (eds). Flavonoids in Health and Disease. Marcel Dekker, Inc., New York, USA. pp. 253-276.

Manzocco, L., Mastrocola, D. \& Nicoli, M.C., 1998. Chain-breaking and oxygen scavenging properties of wine as affected by some technological procedures. Food Res. Int. 31, 673-678.

Marais, J. \& Pool, H.J., 1980. Effect of storage time and temperature on the volatile composition and quality of dry white table wines. Vitis 19, 151-164.

Mayén, M., Barón, R., Mérida, J. \& Medina, M., 1997. Changes in phenolic compounds during accelerated browning in white wines from cv. Pedro Ximenez and cv. Baladi grapes. Food Chem. 58, 89-95.

Mayén, M., Mérida, J. \& Medina, M., 1996. Influence of the addition of sulphur dioxide and must hyperoxidation on the phenolic fractions during vinification of Sherry wines. Food Chem. 56, 7-13. 
Mazza, G., 1995. Anthocyanins in grapes and grape products. Crit. Rev. Food Sci. Nutr. 35, 341-371.

Mazza, G., Fukumoto, L., Delaquis, P., Girard, B. \& Ewert, B., 1999. Anthocyanins, phenolics, and color of Cabernet Franc, Merlot, and Pinot Noir wines from British Columbia. J. Agric. Food Chem. 47, 4009-4017.

McMurrough, I. \& McDowell, J., 1978. Chromatographic separation and automated analysis of flavonols. Anal. Biochem. 91, 92-100.

Nagel, C.W. \& Wulf, L.W., 1979. Changes in the anthocyanins, flavonoids and hydroxycinnamic acid esters during fermentation and aging of Merlot and Cabernet Sauvignon. Am. J. Enol. Vitic. 30, 111-114.

Okuda, T., Takayanagi, T., Sato, M. \& Yokotsuka, K., 2002. Changes in radical scavenging activity of Japanese Cabernet Sauvignon red wines during ageing. J. Wine Res. 13, 93-100.

Pellegrini, N., Simonetti, P., Gardana, C., Brenna, O., Brighenti, F. \& Pietta, P., 2000. Polyphenol content and total antioxidant activity of Vini Novelli (Young red wines). J. Agric. Food Chem. 48, 732-735.

Re, R., Pellegrini, N., Proteggente, A., Pannala, A., Yang, M. \& Rice-Evans, C., 1999. Antioxidant activity applying an improved ABTS radical cation assay. Free Rad. Biol. Med. 26, 1231-1237.

Remy, S., Fulcrand, H., Labarbe, B., Cheynier, V. \& Moutounet, M., 2000. First confirmation in red wine of products resulting from direct anthocyanin-tannin reactions. J. Sci. Food Agric. 80, 745-751.

Remy-Tanneau, S., Le Guernevé, C., Meudec, E. \& Cheynier, V., 2003. Characterization of a colorless anthocyanin-flavan-3-ol dimer containing both carbon-carbon and ether interflavonoid linkages by NMR and mass spectroscopy. J. Agric. Food Chem. 51, 3592-3597.

Ribéreau-Gayon, P. \& Glories, Y., 1986. Phenolics in grapes and wines. In: Lee T. (ed.). Proceedings of the $6^{\text {th }}$ Australian Wine Industry Technical Conference. July 1986. Adelaide, South Australia. pp. 247-256.

Ribéreau-Gayon, P., Glories, Y., Maujean, A. \& Dubourdieu, D., 2000. Phenolic compounds. In: Handbook of Enology Vol. II. pp. 129-185. New York, USA: John Wiley and Sons, Ltd.
Rice-Evans, C.A., Miller, N.J. \& Paganga, G., 1996. Structure-antioxidant activity relationships of flavonoids and phenolic acids. Free Rad. Biol. Med. 20, 933-956.

Schwarz, M., Hofmann, G. \& Winterhalter, P., 2004. Investigations on anthocyanins in wines from Vitis vinifera cv. Pinotage: Factors influencing the formation of pinotin $\mathrm{A}$ and its correlation with wine age. J. Agric. Food Chem. 52, 498 504.

Singleton, V.L., 1987. Oxygen with phenols and related reactions in musts, wines, and model systems: Observations and practical implications. Am. J. Enol. Vitic. 38, 69-77.

Singleton, V.L., Orthofer, R. \& Lamuela-Raventós, R.M., 1999. Analysis of total phenols and other oxidation substrates and antioxidantsb by means of FolinCiocalteu reagent. Methods in Enzymol. 299, 152-178.

Singleton, V.L. \& Rossi, J.R., 1965. Colorimetry of total phenols with phosphomolybdic-phosphotungstic acid reagents. Am. J. Enol. Vitic. 16, 144-158.

Somers, T.C. \& Pocock, K.F., 1990. Evolution of red wines. II. Promotion of the maturation phase. Vitis 29, 109-121.

Timberlake, C.F. \& Bridle, P., 1976. Interactions between anthocyanins, phenolic compounds, and acetaldehyde and their significance in red wines. Am. J. Enol. Vitic. 27, 97-105.

Vidal, S., Cartalade, D., Souquet, J.-M., Fulcrand, H. \& Cheynier, V., 2002. Changes in proanthocyanidin chain length in winelike model solutions. J. Agric. Food Chem. 50, 2261-2266.

Yoshida, T., Mori, K., Hatano, T., Okumura, T., Uehara, I., Komagoe, K., Fujita, Y. \& Okuda, T., 1989. Studies on inhibition mechanism of autoxidation by tannins and flavonoids. V. Radical-scavenging effects of tannins and related polyphenols on 1,1-diphenyl-2-picrylhydrazyl radical. Chem. Pharm. Bull. 37, 1919-1921.

Zafrilla, P., Morillas, J., Mulero, J., Cayuela, J.M., Martínez-Cachá, A., Pardo, F. \& López Nicolás, J.M., 2003. Changes during storage in conventional and ecological wine: Phenolic content and antioxidant activity. J. Agric. Food Chem. 51, 4694-4700. 